\title{
SEDIMENTARY PROCESSES AT THE BASE OF A WEST ANTARCTIC ICE STREAM: CONSTRAINTS FROM TEXTURAL AND COMPOSITIONAL PROPERTIES OF SUBGLACIAL DEBRIS
}

\author{
SLAWEK TULACZYK ${ }^{1}$, BARCLAY KAMB ${ }^{1}$, REED P. SCHERER ${ }^{2}$, AND HERMANN F. ENGELHARDT ${ }^{1}$ \\ ${ }^{1}$ Division of Geological and Planetary Sciences, California Institute of Technology, Pasadena, California 91125, U.S.A. \\ ${ }^{2}$ Uppsala University, Institute of Earth Sciences, 75236 Uppsala, Sweden
}

\begin{abstract}
Samples of sediments from beneath Ice Stream B (at camp UpB), West Antarctica, provide the first opportunity to study the relationship between sediment properties and physical conditions in a sub-ice-stream environment. Piston coring in holes bored by hot-water drilling yielded five 1-3 m long, undisturbed subglacial sediment cores. We analyzed granulometry, composition, and particle morphology in these cores. The UpB cores are composed of a clay-rich, unsorted diamicton containing rare marine diatoms. Sedimentary particles in these cores bear no evidence of the recent crushing or abrasion that is common in other subglacial sedimentary environments. The presence of reworked diatoms and their state of preservation, as well as the relative spatial homogeneity of this diamicton, suggest that the UpB cores sampled a several-meter-thick till layer and not in situ glacimarine sediments. The till does incorporate material recycled from the subjacent poorly indurated Tertiary glacimarine sediments of the Ross Sea sedimentary basin, which extends beneath this part of the West Antarctic Ice Sheet. We propose that the lack of significant comminution in the UpB till is ultimately due to its setting over these easily erodible, clayrich source sediments. The resulting fine-grained till matrix inhibits glacial comminution, because it facilitates buildup of high pore-water pressures and hinders interparticle stress concentrations. Our observations are consistent with the conjecture that subglacial deformation of weak, fine-grained tills does not produce significant comminution of till debris (Elson 1988). Based on our findings, we hypothesize that extensive layers of weak till may develop preferentially where ice overrides preexisting, poorly indurated, fine-grained sediments. Since such weak till layers create a permissive condition for ice streaming, subglacial geology may have an indirect but strong control over the location, extent, and basal mechanics of ice streams.
\end{abstract}

\section{INTRODUCTION}

Ice covers roughly ten percent of the present-day continental area, but glaciers are difficult to investigate as sedimentary agents because of the relative inaccessibility of subglacial environments (Boulton 1987). Studies of glacial sediments from beneath modern ice sheets and glaciers offer the best opportunity to constrain the relationship between their properties and the conditions under which they form. Direct observations of basal and subglacial debris from currently existing ice sheets have been limited to either their margins (e.g., Sugden et al. 1987) or to slow-moving parts drilled for paleoclimatic records (e.g., Gow et al. 1968; Herron and Langway 1979). The drilling project developed by the glaciological group of the California Institute of Technology has offered the first opportunity to sample in situ glacial debris and measure physical conditions at the bed of a fast-moving ice stream (Engelhardt et al. 1990).

There is a considerable interest in mechanics and sedimentary record of ice streams because of the important influence of ice streaming on the mass balance and stability of the modern West Antarctic Ice Sheet (WAIS) and the extensive Late Pleistocene ice sheets (Alley et al. 1986, 1987a; Alley et al. 1997b; Bentley 1987; Blankenship et al. 1986, 1987; Clark 1992; Engelhardt et al. 1990; Hughes 1996; MacAyeal 1992). Over the past two decades, the Ross ice streams (Fig. 1) in West Antarctica have become the focus of extensive glaciological and geological research. There is particular interest in the bed of Ice Stream B at the UpB camp (Fig. 1), where seismic surveys have suggested that the ice stream overrides a several-meters-thick layer of poorly consolidated till (Blankenship et al. 1986, 1987; Rooney et al. 1987). Based on this inference, Alley et al. (1986, 1987a, 1989) have hypothesized that the fast motion of Ice Stream B is accommodated in this till layer, which behaves as a viscous fluid that deforms throughout its thickness and erodes the underlying substrata. This viscous-deforming-bed hypothesis for the till beneath Ice Stream B has been embraced as a new potential mechanism of ice streaming and used to justify reinterpretation of many Pleistocene tills in North America and Europe as former viscously deforming glacial beds (Alley et al. 1987b; Alley 1991; Boulton 1996; Clark 1991; Clark and Walder 1994; and many others). In essence, the subglacial till of Ice Stream B has been used, implicitly or explicitly, as a modern analog for widely distributed till deposits.

Drilling to the bed of Ice Stream B at the UpB camp was undertaken to sample and analyze the seismically imaged subglacial till and to directly study basal processes. Borehole observations have confirmed that this part of the ice stream moves over weak unconsolidated sediments that provide little basal resistance to ice motion (Engelhardt et al. 1990; Kamb 1991; Kamb and Engelhardt 1991). However, they also indicate that sliding on the top of the weak sediment layer, rather than pervasive deformation throughout the layer, may be the predominant mode of ice-stream motion (Engelhardt and Kamb 1997a).

Irrespective of the exact mechanism by which the weak subglacial till facilitates ice stream motion, there is a consensus that its presence is essential for the existence of Ice Stream B, and that location of other ice streams may be predetermined by presence of similar layers of weak till (Alley et al. 1986; Echelmeyer et al. 1994; Kamb 1991; Smith 1997). Therefore, it is of fundamental importance to understand the origin of the sub-ice-stream till and the relationship between sediment properties and geologic as well as glaciologic factors.

In this study, we investigate compositional and textural properties of the unconsolidated sediments recovered in five 1-3 m long cores from beneath Ice Stream B in the UpB camp area (Fig. 1). We first evaluate the sedimentological data to verify whether the recovered bed material is a glacial till. Next, we analyze how the subglacial physical conditions and the geologic setting of the ice stream control the sediment characteristics.

\section{GLACIOLOGIC AND GEOLOGIC SETTING}

Ice Stream B is one of five Ross ice streams that flow into the Ross Ice Shelf (Fig. 1). At the UpB camp, the ice stream is $30 \mathrm{~km}$ wide and $1 \mathrm{~km}$ thick, and has an average surface slope of about 0.0013 . The ice base is roughly $600 \mathrm{~m}$ below sea level. Given these conditions, the gravitational driving stress is low, 13-20 kPa, yet the ice stream moves at c. $440 \mathrm{~m} \mathrm{yr}^{-1}$ (Whillans and van der Veen 1993). The motion is plug flow over a bed lubricated by water and weak sediments (Alley et al. 1986; Kamb 1991). Shear margins, about $5 \mathrm{~km}$ wide, separate the ice stream from the adjacent ice sheet, which moves approximately two orders of magnitude slower (Echelmeyer et al. 1994; Jackson and Kamb in press).

Borehole measurements show that the base of the ice stream is at the pressure melting point of $-0.8^{\circ} \mathrm{C}$. Presumably, the ice base feeds meltwater into a widespread basal water system (Engelhardt and Kamb 1993). The water pressure in this system is very high, only c. $50 \mathrm{kPa}$ lower than the ice overburden pressure of about 9 MPa (Blankenship et al. 1986, 1987; Engelhardt and Kamb 1997b). The pore fluid saturating the unfrozen sub- 


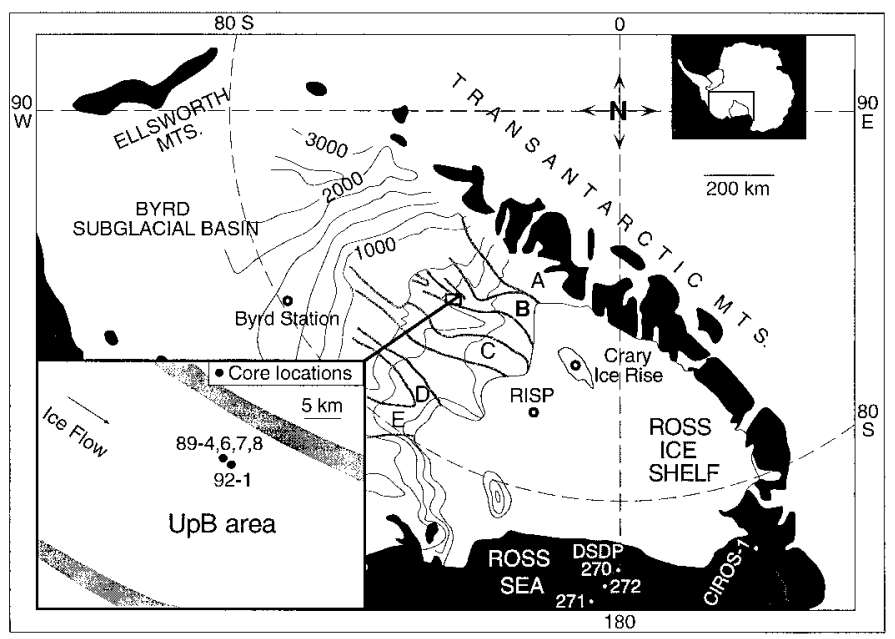

FIG. 1.-Location of the study area in West Antarctica. Letters A through E denote the individual Ross ice streams. Shear margins of the ice streams and ice elevation contour lines at $250 \mathrm{~m}$ spacing are from Whillans and van der Veen (1993, fig. 1); base map and position of mountain ranges and nunataks (in black) are from Bentley (1982, fig. 1). The inset shows the core sampling locations in the UpB camp area.

glacial sediments is fresh water, most likely derived from the basal melting (Kamb and Engelhardt 1991). Borehole experiments indicate that 69-83\% of the ice stream velocity is accommodated by basal sliding sensu lato, which may include a contribution of till deformation immediately below the base of the ice, confined to a shear zone that is several centimeters thick (Engelhardt and Kamb in press). Henceforth, we will refer to this motion mechanism as basal sliding.

The subglacial geology of the West Antarctic interior basins has been deduced mostly from geophysical data. Blankenship et al. $(1986,1987)$ and Rooney et al. $(1987,1991)$ inferred from seismic studies in the UpB area that a several-meters-thick till layer unconformably overlies a bedded sedimentary sequence of at least $600 \mathrm{~m}$ thickness. Low seismic velocities indicate that the till layer and the underlying sequence are poorly lithified. The sedimentary sequence beneath the ice stream may represent a southeastward extension of the Ross Sea basin, where a c. 20-m-thick layer of Plio-Pleistocene tills (Ross Sea Tills) overlies a several-hundred-meterthick Late Tertiary glacimarine sequence (Anderson et al. 1980; Anderson et al. 1984; Barrett 1975a; Hayes et al. 1975; Kellogg et al. 1979; Rooney et al. 1991). Regional gravimetric and magnetic studies also suggest that the Ross Sea basin extends beneath part of the WAIS (Jankowski and Drewry 1981; Savage and Ciesielski 1983). This view is supported by the few geological samples recovered from the West Antarctic interior basins (Crary Ice Rise, Bindschadler et al. 1988; Byrd Station, Gow et al. 1968; Ross Ice Shelf at site J9, Webb 1979, Scherer 1994) (locations in Figure 1).

\section{CORE SAMPLING}

For the sediment sampling, a hot-water drill was used first to melt a c. $10 \mathrm{~cm}$ diameter borehole. Not less than four hours after borehole completion a piston corer of $6 \mathrm{~m}$ length and internal diameter of $5 \mathrm{~cm}$ was deployed to sample the unfrozen subglacial sediments. During 1989-90, we acquired four cores $(89-4,89-6,89-7,89-8)$ from a closely spaced $(<200$ m) cluster of boreholes near the UpB camp (Fig. 1). A single core (92-1) was recovered in 1992-93 from a bed location roughly $1300 \mathrm{~m}$ downstream of the 1989 sites. Henceforth we will refer to these five cores as the UpB cores. In several other holes drilled throughout the UpB area, macroscopically identical sediments were sampled in small amounts by piston coring with shallow penetration, by winnowing with the hot-water jet, or by sed- iment being stuck to borehole instruments that were lowered to the bottom and penetrated c. $0.2 \mathrm{~m}$ into the basal sediment. During the 1995-96 season such sediments were also encountered beneath ice c. $10 \mathrm{~km}$ upstream from the locations discussed in this paper.

The sediment cores show no evidence of disturbance (e.g., grading or sorting) by the jet action of the hot-water drill, although such disturbance undoubtedly occurs during borehole drilling. We attribute the lack of disturbed material in the cores to the fact that the ice slides at $3-4 \mathrm{~cm} / \mathrm{hr}$ (Engelhardt and Kamb in press): during the few hours between completion of a borehole and piston coring, the bottom of each borehole moves away, by sliding, from the disturbed bed area and onto adjacent undisturbed bed, from which the core sample is then obtained.

\section{LABORATORY METHODS}

The five UpB cores were analyzed by standard sedimentological methods. The cores and their x-ray radiographs were first examined for macroscopic sedimentary structures and downcore changes in the abundance of pebbles coarser than $-2 \phi(>4 \mathrm{~mm}$ diameter). Two hundred and thirty clasts were extracted from the UpB cores and examined for lithology, roundness (method of Krumbein 1941), and presence of glacial facets, striations, and other surface markings. Grain-size distribution was analyzed by sieving and pipetting (Galehouse 1971b, p. 71 and 81-88) on 35 samples spaced at c. $0.3 \mathrm{~m}$ along each core. Grain mounts of the sand-size fraction 1-2 $\phi$ were prepared from the same samples, for mineralogical analysis. In addition, mineral composition of all size fractions ( $1 \phi$ interval) smaller than $-2 \phi$ was determined for two arbitrarily selected samples (89-4-20, 92-1-50). Mineralogy of three hundred grains was determined in each grain mount (Galehouse 1971a, p. 391-392). X-ray diffraction (XRD) analyses gave a semiquantitative estimate of mineralogy for clay and silt size fractions (smaller than $8 \phi$, and 4-8 $\phi$, respectively) (Griffin 1971; Haldorsen 1977).

Scanning electron microscopy (SEM) was used to analyze micromorphology of quartz and feldspar grains in the sand size range, from $2 \phi$ to $3 \phi$. The analysis involved checking for the presence/absence of selected microfeatures on thirty grains of each mineral in each sample studied. The microfeatures were defined based on the work of Berner and Holdren (1977, 1979), Darmody (1985), Douglas and Platt (1977), Holdren and Berner (1979), Krinsley and Doornkamp (1973), Margolis and Kennett (1971), and Mazzullo and Ritter (1991). To the microfeature data we apply a modification of the weathering score method of Darmody (1985), which was designed to semiquantitatively assess the relative influence of physical breakage and chemical weathering on sand grain micromorphology. In this method, each grain is checked for five selected chemical weathering microfeatures (\#1-5, Table 1) and five physical breakage microfeatures (\#610 , Table 1); points are scored +1 for the presence of each of the former and -1 for the presence of each of the latter. The sum of the points is the weathering score for a grain and the scores for thirty grains are averaged to get the score for a sample.

For calibration of the results, we produced and identified the microfeatures in five artificially treated samples of quartz and feldspar grains in the same size range $(2-3 \phi)$. One of the samples was prepared by crushing $-1 \phi$ to $0 \phi$ size grains from the UpB sediments with a mortar and pestle. In three other samples the crushed grains were treated for $24 \mathrm{hr}$ with $1 \%$ $\mathrm{HF}, 10 \% \mathrm{HF}$, and $5 \% \mathrm{NaOH}$, respectively. A fifth sample consisted of crushed grains that were subsequently tumbled in a till slurry at $40 \mathrm{rpm}$ for $28.5 \mathrm{hr}$ (linear displacement of c. $20 \mathrm{~km}$ ).

The abundance of whole diatoms and diatom fragments was determined on sediment samples of c. $50 \mathrm{~g}$. The samples were dried $\left(50^{\circ} \mathrm{C}\right)$, weighed, and disaggregated in $100 \mathrm{ml}$ of hot water $\left(90^{\circ} \mathrm{C}\right.$ ). A 2.5 (1 aliquot from a sample suspension homogenized by vigorous shaking was used to prepare a strewn slide on a microscope cover glass. This method does not produce a true random distribution of particles (Laws 1983), but clumping or other 


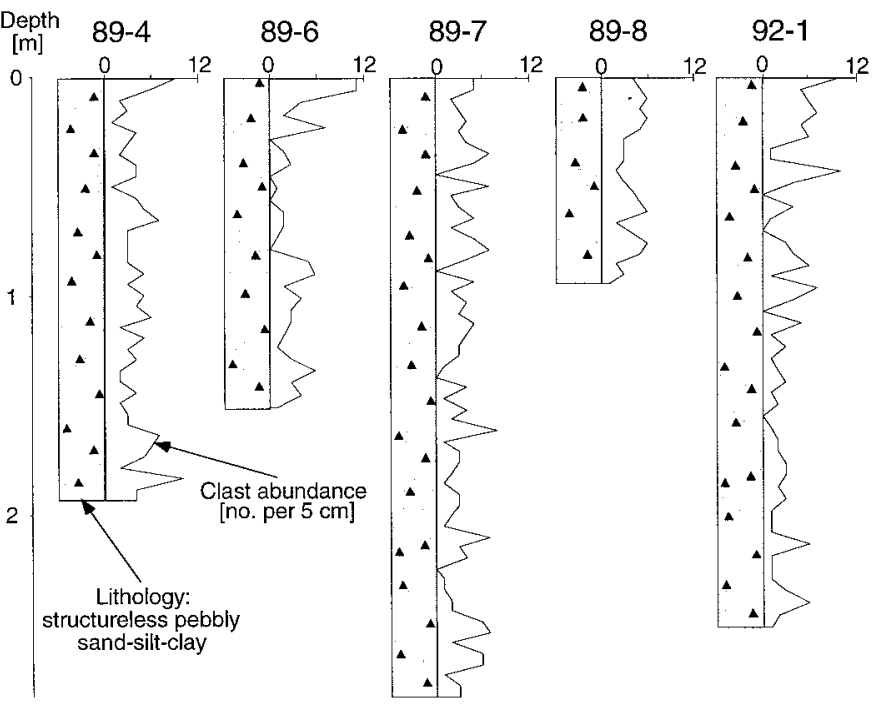

FIG. 2.-Lithology and variations in clast abundance within the five UpB cores.

obvious distributional bias is minimized. Edge-to-edge transects were counted on an Olympus interference contrast microscope with a $60 \times$ oil objective. The abundances obtained with this method should be considered as relative figures, since accuracy of this method has not been rigorously tested.

\section{RESULTS}

Individual sediment samples to which we refer in the paper are identified with a sample number (e.g., 89-4-20) made up of the core number (e.g., 89-4) and the depth of the sample below the top of the core, in centimeters (e.g., $20 \mathrm{~cm}$ ). The core numbers appear at the corresponding locations in Figure 1. When it was not practical, because of time constraints, to analyze certain sediment characteristics (e.g., microfeatures on sand grains) in many samples from the UpB cores, we selected samples from near the core tops. This is motivated by our belief that the sediments from near the base of the ice should be most strongly affected by the modern subglacial processes operating beneath Ice Stream B (Engelhardt and Kamb in press).

\section{Structure}

The five UpB cores are macroscopically and microscopically structureless and consist of very dark gray ( $5 \mathrm{Y} 3 / 1$, when wet) sand-silt-clay matrix with scattered pebbles. The distribution of pebbles is spatially variable but shows no discernible grading or bedding (Fig. 2), including at the recovered core tops.

\section{Texture and Composition}

The UpB cores consist of an extremely poorly sorted diamicton. The diamicton has a bimodal grain-size distribution with one mode in the fine sand fraction $(2-4 \phi)$ and the second in the clay fraction finer than $10 \phi$ (Fig. 3A). We must point out here that the grain-size distribution reported earlier for one sample of the UpB diamicton (Engelhardt et al. 1990, their figure 2) erroneously omitted the clay size fraction.

Clasts (greater than $-2 \phi$ ) constitute on average c. $3 \%$ of the UpB diamicton (Fig. 3A). A number of different lithologies with highly variable mineral composition comprise the 230 clasts extracted from the UpB cores. Crystalline rock fragments (33\% gneisses, $27 \%$ schists, $23 \%$ plutonics, $3 \%$ volcanics) predominate over sedimentary rock fragments (8\%) and quartz fragments $(6 \%)$. The clasts are mainly subangular and subrounded in shape with facets present on $50 \%$ of them. However, on c. $25 \%$ of the faceted

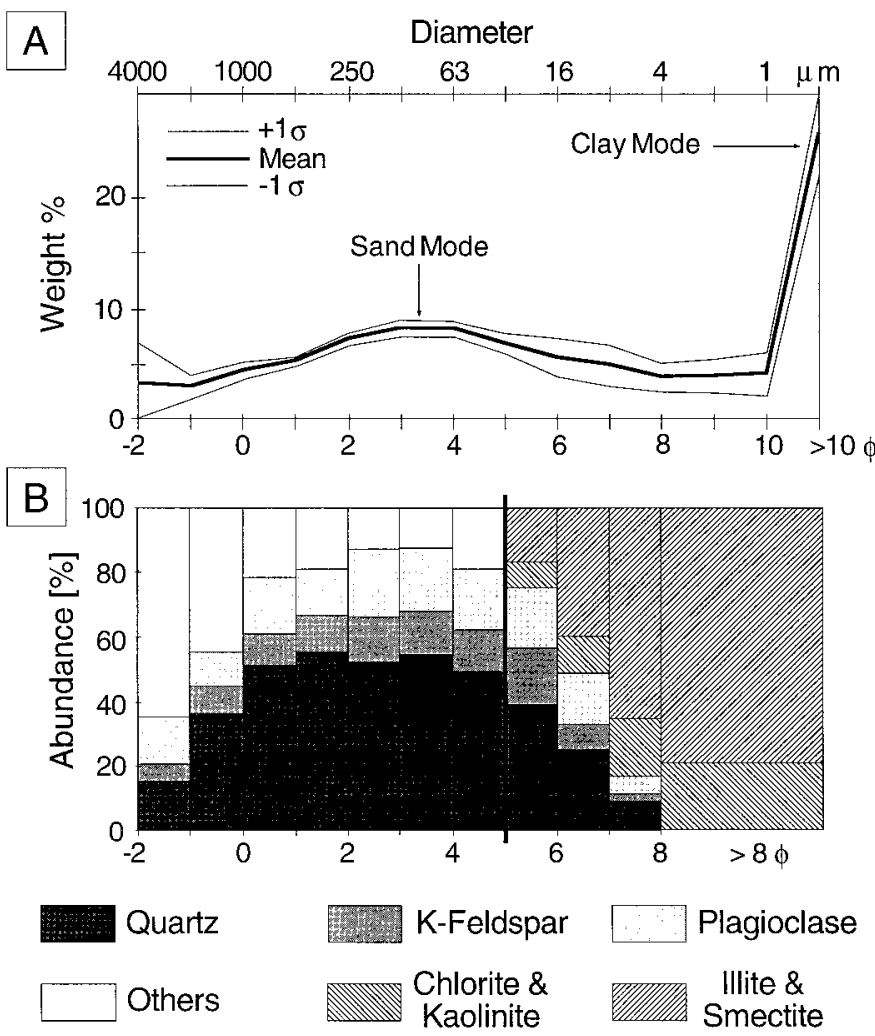

FIG. 3.-A) Grain-size distribution diagram showing the mean \pm one standard deviation for 35 samples from all five cores. B) Changes in mineralogy with grain size in one sample (92-1-50). The composition-size spectrum of another randomly selected sample (89-4-20) is indistinguishable from the one displayed here (within the limits of the applied analytical methods). The category "others" in B encompasses lithics, muscovite, biotite, chlorite, amphibole, and pyroxene. The vertical solid line in the same diagram marks the $5 \phi$ size boundary. Composition of grains greater than $5 \phi$ was determined by optical mineralogy with relatively low standard error, $0-4 \%$. The XRD determinations of mineralogy for the size fractions smaller than $5 \phi$ are semiquantitative.

clasts the facet planes have macroscopic etch pits, which are frequently developed in mafic minerals or plagioclase and are sometimes lined with weathering products. Glacial polish and striations are essentially absent; only two clasts $(0.9 \%)$ showed questionable striations.

The sand-size particles in the UpB diamicton are composed on average of $59 \%$ ( $\pm 5 \%$, one standard deviation) quartz, $27 \%$ ( $\pm 3.5 \%$ ) feldspar, and $16 \%( \pm 3.5 \%)$ lithics (35 samples of the size range 1-2 $\phi$ ). Quartz and feldspar also make up almost all of the coarse silts (4-5 $\phi)$, but toward finer grain size the content of clay minerals increases rapidly (c. 20\% per $1 \phi$ interval) to $100 \%$ in the clay size fraction (Fig. 3B). The latter is composed solely of clay minerals (c. $60 \%$ illite, $20 \%$ smectite, $10 \%$ kaolinite, and 10\% chlorite).

Our SEM analysis on size fraction 2-3 $\phi$ from two UpB samples (894-20, 92-1-0) indicates that sand micromorphology in this sediment is dominated by chemical weathering microfeatures (\#1-5, Table 1) that overprint older physical breakage microfeatures (\#6-10, Table 1). This observation can be illustrated using as examples the two grains in Figure 4A and B. Both of them have older fracture planes and steps marked by small but abundant etch pits. Fine details typically produced by breakage (e.g., arcuate steps on quartz, Fig. 4C) are not present on these grains, presumably because they became obliterated by chemical alteration. The microfeature frequency data and the weathering scores calculated with the modified method of Darmody (1985) also reflect the combined influence of older grain breakage and subsequent chemical alteration on sand micromorphol- 
TABLE 1.-Quartz and feldspar microfeatures. Quartz microfeatures are from Dormody (1985).

\begin{tabular}{rll}
\hline \hline$\#$ & \multicolumn{1}{c}{ Quartz } & \multicolumn{1}{c}{ Feldspar } \\
\hline 1 & Etch pits & Rounded edges \\
2 & Hairline cracks & Etch pits \\
3 & Rounded edges & Crevasses \\
4 & Precipitation or solution of silica & Karst-like surfaces \\
5 & Irregular roughness & Irregular roughness \\
6 & Conchoidal fracture & Sharp edges \\
7 & Sharp edges & Cleavage planes \\
8 & Smooth fracture planes & Fracture steps \\
9 & High relief & Fracture-propagation cracks \\
10 & Arcuate steps & Cleavage-parallel lines \\
\hline
\end{tabular}

* Feldspar microfeatures were defined mainly by analogy with the quartz microfeatures during our initial SEM investigations. In addition, we used work by Berner and Holdren $(1977,1979)$ and Holdren and Berner (1979) to define the microfeatures produced by chemical alteration of feldspar grains. The physical breakage microfeatures are given in italic type, the chemical alteration microfeatures by roman type.

ogy in the analyzed UpB samples (Fig. 5). In terms of their microfeature frequency distribution and weathering scores these two samples are similar to the artificially prepared sample of grains that were crushed and subsequently treated with relatively strong (10\%) HF (Fig. 5). At the same time, the UpB samples show little affinity to the samples of grains that were freshly crushed, tumbled in a rock tumbler, or treated with weak $\mathrm{NaOH}$ or HF (Figs. 4, 5). Microfeatures that are typically produced by abrasion (striations and grooves), high-energy aqueous environments (v-pits), and severe diagenesis (silica flowers and globules) (Krinsley and Doornkamp 1973) are rare or absent on the grains from the UpB diamicton (data not shown).

In addition to the rock and mineral debris, the UpB sediments contain a variety of microfossils with a strong predominance of Miocene marine diatoms (Scherer 1989, 1991). Data from the Core 92-1 suggest that abundance of diatom shells and their fragments is higher by roughly an order of magnitude near to the ice base than below the uppermost few centimeters of the cores (Table 2). These data are consistent with qualitative observations from other UpB sampling locations, where whole or nearly whole diatoms were also found, mainly in the material from near the ice base, yet are extremely rare in down-core samples (Scherer 1994 and unpublished data).

\section{DISCUSSION}

\section{Recognition Of Till}

A key question is whether the five analyzed $\mathrm{UpB}$ cores are representative of either the widespread till layer or the glacimarine sediments inferred to be present beneath the UpB area of Ice Stream B (Blankenship et al. 1986, 1987; Rooney et al. 1987, 1991).

The UpB cores contain a structureless diamicton, and none of the sedimentological properties we have discussed is highly variable within or between the cores. The apparently structureless character of the UpB diamicton suggests it is a till, and its relative homogeneity is consistent with glacial sediment mixing, which may produce till sheets that are homogeneous over large areas (hundreds to thousands of square kilometers; Kemmis 1981). In order to be classified as a proper glacial till, the UpB diamicton must meet the three basic criteria contained in the definition of till (Dreimanis 1988, p. 34). According to this definition a glacial till must: (1) be deposited in a close spatial relationship to a glacier, (2) lack evidence for sorting by water, and (3) contain debris that has been transported and deposited by ice. The UpB diamicton meets the first two criteria, but it is difficult to demonstrate conclusively the third one. Perhaps the best argument for glacial sediment transport and mixing in the $\mathrm{UpB}$ diamicton is provided by the presence of marine microfossils of a mixture of ages (including Paleozoic palynomorphs, Tertiary diatoms, and other microfossils, as well as rare Quaternary diatoms; Scherer 1991 and unpublished data). Diatoms and other fossils reworked from preexisting sediments of different ages have been used to argue for subglacial origin of most marine diam-
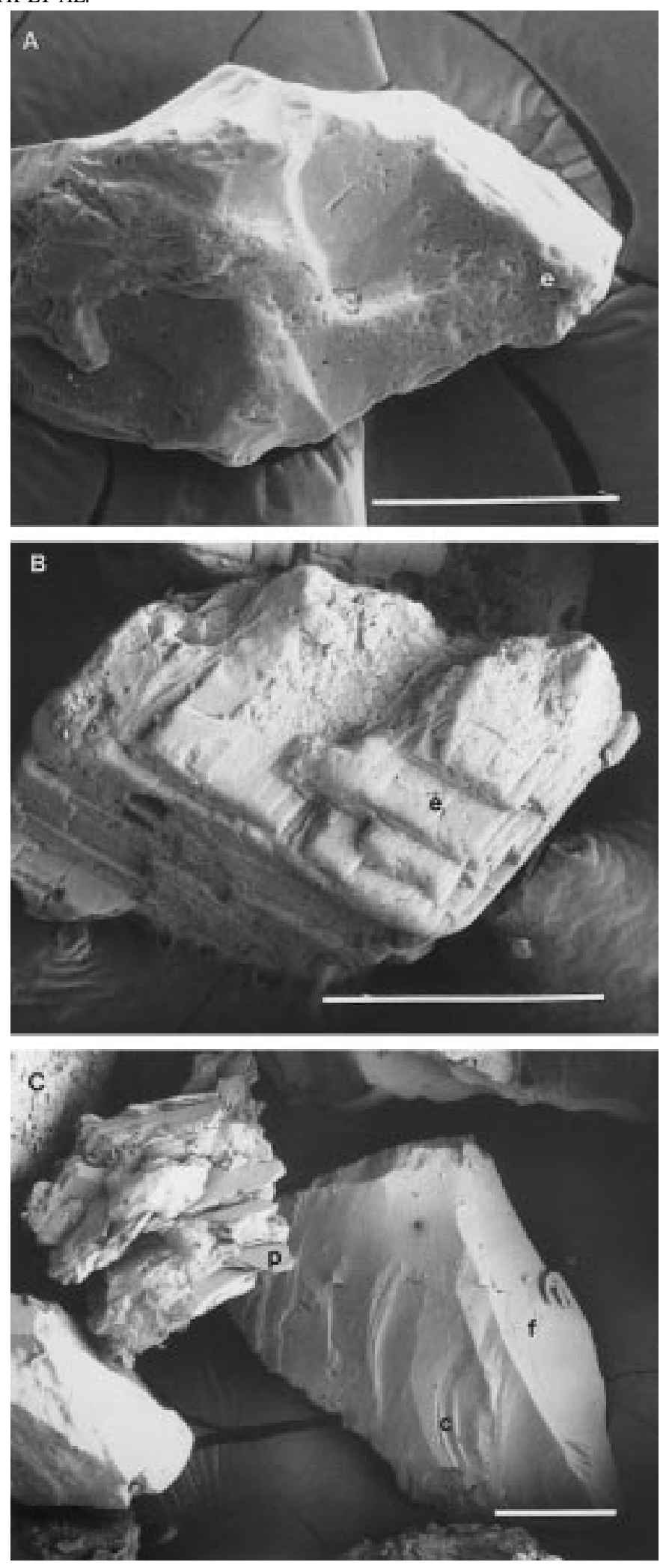

FIG. 4. - SEM microphotographs of sand grains ( $2-3 \phi$ diameter) from $\mathbf{A}, \mathbf{B})$ the UpB till and $\mathbf{C}$ ) an artificially crushed sample. The scale bars are $0.1 \mathrm{~mm}$ long in all of the photomicrographs. A quartz grain from the sample 89-4-20 (A) shows dull old fracture planes covered with etch pits (e) and separated by rounded edges. A feldspar grain from the same sample (B) has etch pits (e) and rounded edges. Freshly crushed grains $(\mathrm{C})$ have very sharp edges combined with flat cleavage planes (p) on feldspar (upper left) and with flat (f) and conchoidal (c) fracture planes on quartz (center right). 

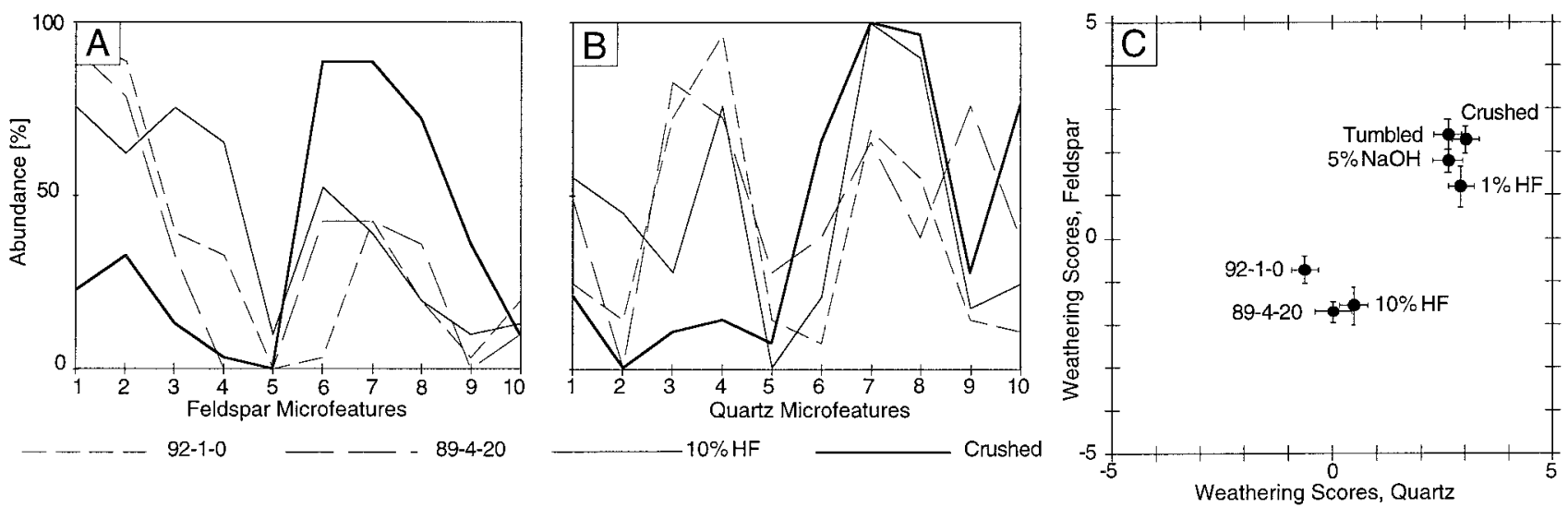

FIG. 5.-Relative abundance of chemical weathering (\#1-5) and crushing (\#6-10) microfeatures on A) feldspar and $\mathbf{B}$ ) quartz sand grains (2-3 $\phi$ ) in two real and two artificial analyzed samples. The three remaining artificial samples, $1 \% \mathrm{HF}, 5 \% \mathrm{NaOH}$, and Tumbled, have microfeature frequency distributions indistinguishable from that of the sample of crushed grains. The individual microfeatures are coded with the same numbers as in Table 1, and artificial samples are described in the Laboratory Methods section of this paper. C) Weathering scores (Darmody 1985) calculated from the data in A and B. Negative weathering scores indicate predominance of chemical weathering microfeatures over physical breakage microfeatures; positive weathering scores mean the opposite. Bars are one standard error from the mean. The axes on the diagrams span the whole possible range of values for the weathering scores $(+5$ to -5$)$.

ictons from West Antarctica, including Ross Sea diamictons (RSD) (Kellogg et al. 1979), Site J-9 of the Ross Ice Shelf Project (RISP) (Harwood et al. 1989), and Crary Ice Rise (CIR) (Scherer 1994). The relative paucity of whole diatoms in the UpB diamicton (e.g. $\sim 10^{4}$ per gram, Table 2, vs. $\sim 10^{7}$ per gram in the RISP material) is consistent with mechanical or chemical disintegration of the fragile diatom shells during formation of this material by glacial processes.

From this evidence, we deduce that the UpB cores did not directly sample Tertiary glacimarine sediments, which are inferred to be present only several meters beneath the ice base (Rooney et al. 1991), but instead they sampled the top 1-3 $\mathrm{m}$ of the widespread, seismically imaged layer inferred to be a till that lies between the in situ glacimarine sediments and glacial ice (Blankenship et al. 1986, 1987; Rooney et al. 1987).

\section{Lack of Comminution}

Even though the presence of evidence for subglacial comminution (i.e., subglacial crushing and abrasion) is not included as a criterion in the definition of till (Dreimanis 1988, p. 34), such evidence is so common in tills that it is widely considered as their most important distinguishing feature (e.g., Dreimanis 1990; Harland et al. 1966). We here review the sediment characteristics commonly used as indicators of glacial comminution (striations, glacial polish, glacial flour, abundant freshly broken particles) and discuss their absence in the UpB till.

Striations represent the most dependable indicator of glacial clast wear (Harland et al. 1966). They are present on 6-57\% of the clasts from Late Cenozoic glacial and glacimarine sediments from the Ross Sea (Barrett 1975b; Domack et al. 1980; Hall 1989) and on 3-84\% of the clasts in several North American Pleistocene tills (Anderson 1955; Drake 1972; Holmes 1952). Since the UpB clasts are similar in size and lithology to the striated clasts studied in the Ross Sea sediments (e.g., Barrett 1975b),

TABLE 2.-Abundance of diatoms and diatom fragments from different parts of Core 92-1, in 10,000 counts per gram.

\begin{tabular}{lccc}
\hline \hline \multicolumn{1}{c}{ Diatoms } & $\begin{array}{c}92-1-0 \\
(\text { core top) }\end{array}$ & $\begin{array}{c}92-1-140 \\
\text { (core center) }\end{array}$ & $\begin{array}{c}92-1-270 \\
\text { (core bottom) }\end{array}$ \\
\hline Small fragments $(<10 \mu \mathrm{m})$ & 251 & 4 & 18 \\
$<1 / 4$ of a diatom & 75 & 1 & 2 \\
$1 / 4-1 / 2$ of a diatom & 5 & 0 & 0 \\
$>1 / 2$ of a diatom & 5 & 0 & 0 \\
Whole diatom & 1 & 0 & 0 \\
\hline
\end{tabular}

the observed lack of striations cannot simply result from a lesser susceptibility of the examined clasts to abrasion. Another sensitive indicator of abrasion, glacial polish, is also absent from the studied UpB clasts. Even though about $50 \%$ of the clasts are faceted, the presence of pitted facet surfaces suggests that chemical alteration followed an earlier stage of facet generation. All these observations indicate an insignificant extent of recent clast wear beneath Ice Stream B.

Comminution debris composed of silt- and clay-size quartz and feldspars (glacial flour) frequently represents a prominent mode in tills (Dreimanis and Vagners 1969, 1971; Haldorsen 1977, 1981, 1983). The clay size fraction of the UpB till lacks any non-clay minerals (quartz and feldspar) that could result from comminution (e.g., Fig. 3B). Granulometrically and compositionally, the silt size fraction in this till is a mixture of the sandy and clayey modes rather than an independent mode (Fig. 3A, B). These clayrich silts could not be generated to a significant degree by closed-system comminution of larger particles (sands and clasts) that are composed almost entirely of quartz and feldspars. Compared to typical tills, the matrix of the UpB till is low in silt content (Fig. 6). There is thus no indication that the fines of the UpB till are products of glacial comminution of the coarser particles or hard bedrock.

Glacial crushing of larger rock fragments is a common source of sandsize particles in glacial deposits (Dreimanis and Vagners 1969, 1971; Haldorsen 1983). Such particles should have sharp edges and abundant fresh breakage microfeatures (Sharp and Gomez 1986). In contrast, sand grains in the UpB till show little indication of fresh crushing and have predominantly rounded edges. Rounded edges are sometimes thought to result from glacial abrasion (Mazzullo and Anderson 1987), but in the UpB till they are associated with chemical weathering microfeatures (e.g., etch pits) (Figs. 4, 5). Qualitative evaluation of crosscutting relationships between different microfeatures on the $\mathrm{UpB}$ sand grains provides no evidence for significant grain edge abrasion and suggests that chemical alteration dominated the most recent episode of grain surface evolution. In addition, our simulation of subglacial grain abrasion in a rock tumbler did not produce any detectable changes in sand grain micromorphology (Fig. 5), supporting earlier inferences of other workers that sand grains do not experience significant edge abrasion in subglacial environments (Sharp and Gomez 1986; Whalley 1978).

Since there are no direct constraints on chemical weathering rates beneath Ice Stream B, it is difficult to estimate the time necessary for development of the weathering features observed on the UpB clasts and sand 


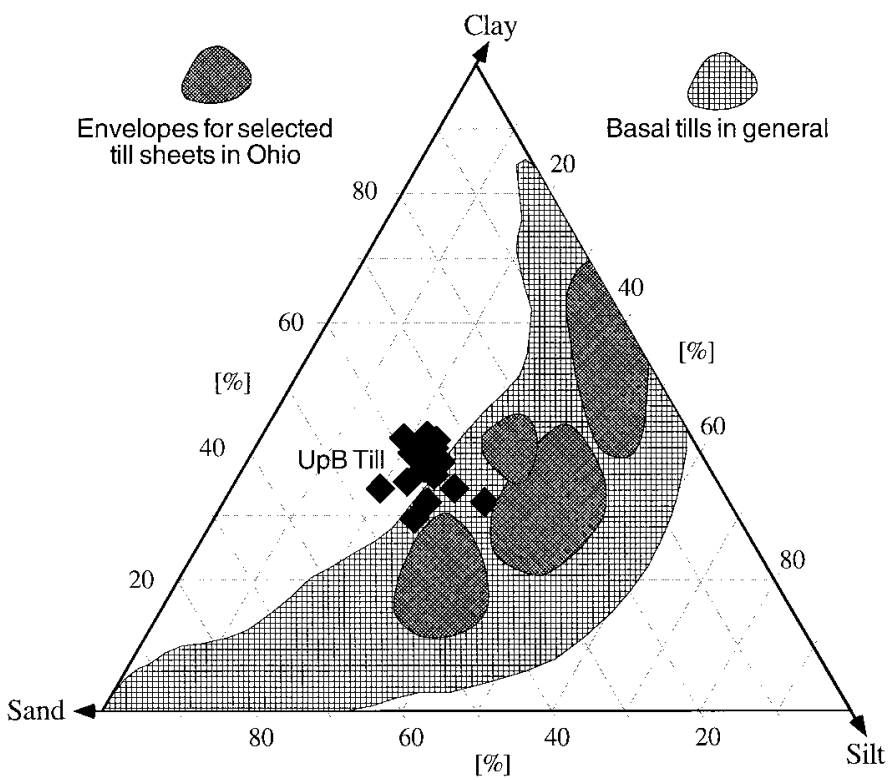

FIG. 6.-Comparison of the sand-silt-clay composition of the UpB till samples (solid diamonds) with an envelope for basal tills in general and selected individual till sheets from Ohio (modified from Sladen and Wrigley 1983, fig. 8.1a). grains. However, observational evidence from several North American tills exposed to soil weathering indicates that fresh breakage features have survived on glacially crushed quartz grains presently exposed to soil weathering for at least $\sim 10^{5}$ years (Douglas and Platt 1977; Mahaney 1995). It is believed that, because of low throughput of water and $\mathrm{CO}_{2}$, chemical weathering beneath large ice masses is slower by one or more orders of magnitude than subaerial weathering (Kump and Alley 1994; Rosenqvist 1962, 1975). Fresh-looking crushed quartz grains may survive for $\sim 10^{6}$ years in environments of low chemical agressivity (Kanaori et al. 1985, fault gouges; Margolis and Kennett 1971, deep-sea sediments). Thus, the chemical weathering features on grains and clasts from the UpB till probably took at least the last $10^{5}$ years to develop, and in the same time period, physical comminution of the till debris was negligible.

\section{Sediment Recycling from the Ross Sea Sequence}

Since the debris in the UpB till was not generated mechanically under the present-day subglacial conditions, an alternative model must explain its characteristics. The sediment in tills may be derived by glacial comminution of preexisting sediments and bedrock (e.g., Dreimanis and Vagners 1969, 1971; Haldorsen 1977, 1981, 1983) or by incorporation of preexisting unconsolidated sediments (e.g., Elson 1988, Gillberg 1977). In the case of the UpB till, the source of this preexisting material was probably the (inferred) underlying Tertiary glacimarine sediments of the Ross Sea sequence (Rooney et al. 1991). This proposition is supported by the strong sedimentological similarity between the UpB till and the Ross Sea tills and glacimarine sediments (Fig. 7).

The reworked marine microfossils of multiple ages provide the most fundamental evidence for incorporation of sediments from different Ce-

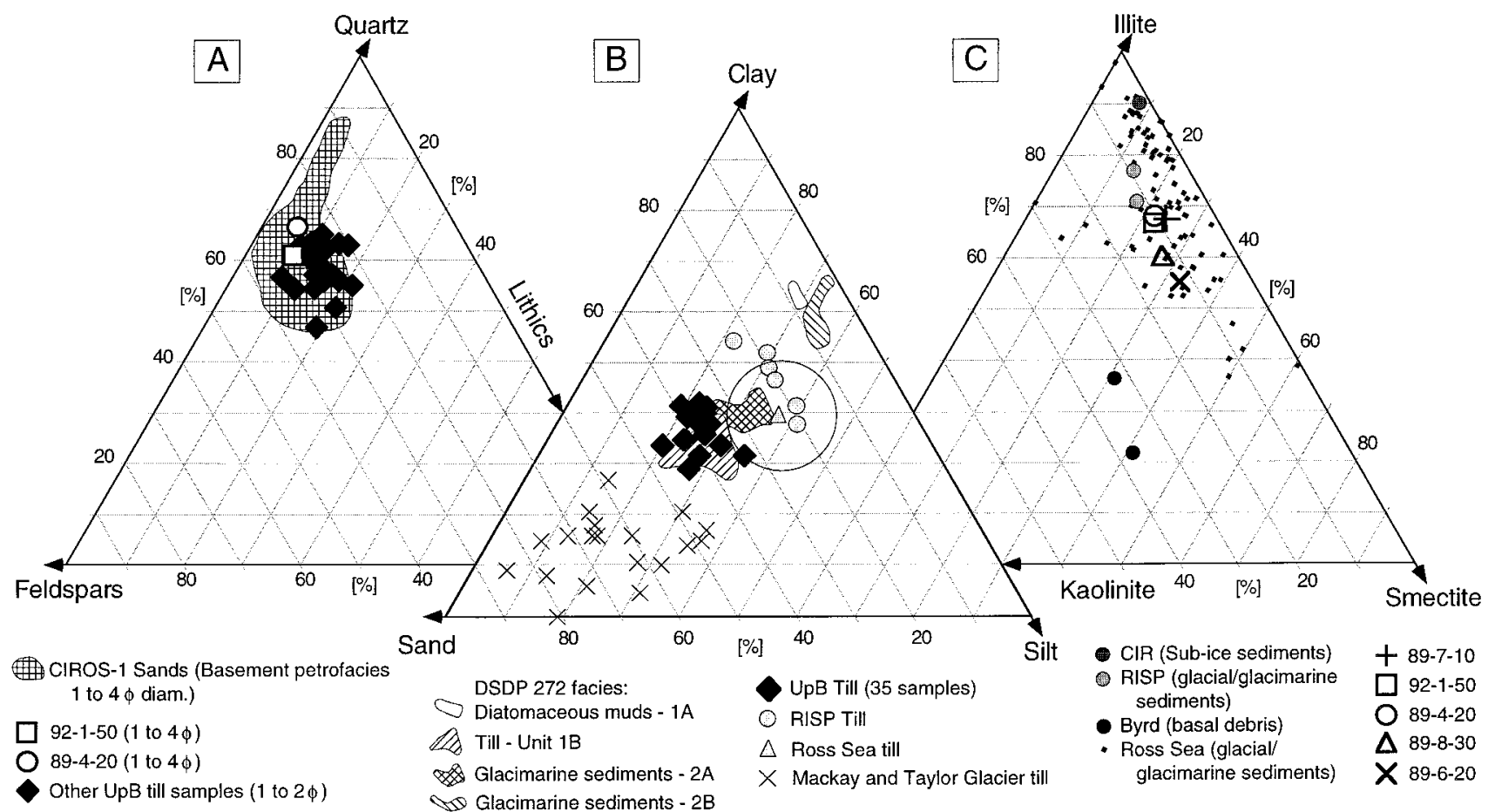

FIG. 7.-Comparison of the UpB till with the glacigenic deposits from the Ross Sea sedimentary basin. A) Quartz-feldspar-lithics composition of sand fraction (1-4 $\phi$ ) from two selected samples $(92-1-50,89-4-20)$ and the sand fraction $(1-2 \phi)$ for 33 remaining samples from the UpB till along with the composition of the sand fraction $(1-4 \phi)$ from Tertiary glacigenic sediments in the CIROS-1 core (Basement Petrofacies in George 1989, fig. 4). B) Comparison of the sand-silt-clay size distribution for the UpB till matrix (35 samples) with other basal tills and glacimarine deposits from the Ross Sea region. Data for the Ross Sea till (mean shown by shaded triangle, estimate of one standard deviation by large open circle) is from Anderson et al. (1980, fig. 3), RISP till from Webb (1979, fig. 15), Mackay and Taylor Glacier till from Ross D. Powell (1995, personal communication), and DSDP 272 facies from Hayes, Frakes, et al. (1975, fig. 5, p. 219). C) Illite-smectite-kaolinite plot comparing samples from the five UpB cores with glacigenic sediments from the Crary Ice Rise (CIR), Ross Ice Shelf Project (RISP), Byrd Station (Byrd), and the bottom of Ross Sea. Data for the four latter locations from Turner (1992). 
nozoic marine strata into the UpB till (Scherer 1991). The presence of c. $35 \%$ of clay minerals in the till provides additional supportive evidence, because subglacial chemical weathering does not produce a significant amount of clays (Rosenqvist 1962, 1975). Thus, it is frequently accepted that clays in tills are recycled from preexisting fine-grained sediments and rocks (Karrow 1976; Mickelson et al. 1983). The Ross Sea sedimentary sequence is a suitable source of clays for the UpB till, in terms both of clay abundance and mineralogy (Fig. 7). In terms of sand-silt-clay composition, the UpB till is practically indistinguishable from both the Ross Sea tills (Unit 1B, Fig. 7B) and the Miocene Ross Sea glacimarine sediments (Unit 2A, Fig. 7B), but it is significantly more clay rich than debris from the modern land-based glaciers flowing into the Ross Sea (Mackay and Taylor glaciers, Fig. 7B).

Composition and micromorphology of sand particles from the UpB till is also consistent with recycling of this size fraction from the Ross Sea sedimentary sequence (Fig. 7A). The age of this source material matches the $>10^{5}$ years timescale that is likely needed to create the chemical alteration features present on the UpB sand grains and clasts. Bridle and Robinson (1989) observed such features on quartz grains from the Ross Sea sequence in the CIROS-1 core, in McMurdo Sound, Antarctica.

In summary, the granulometric data and the age of microfossils suggest that the UpB till has been derived mainly from the Miocene strata of the Ross Sea sequence (Scherer 1989, 1991, 1994). Deep drilling in the Ross Sea (Fig. 1) shows Miocene glacimarine pebbly muds and diatomaceous muds lying unconformably beneath widespread Plio-Pleistocene diamictons, generally believed to have been deposited by grounded ice (Anderson et al. 1980; Anderson et al. 1984; Barrett 1975a; Kellogg et al. 1979; Savage and Ciesielski 1983). We hypothesize that a similar stratigraphy exists beneath Ice Stream B at the UpB camp.

\section{Relation of Sediment Properties to Subglacial Processes}

The debris in the UpB till appears not to have experienced significant glacial reshaping. Instead, its properties were largely formed by glacimarine processes that dominated this part of the Ross Sea sedimentary basin before encroachment of the West Antarctic Ice Sheet several million years ago (Hayes and Frakes 1975). This observation implies that the till did not experience stresses high enough to induce significant crushing and abrasion throughout the entire history of its derivation, transport, and deposition. Unfortunately, conclusive constraints on the exact history of the UpB till are lacking. We thus consider only two end-member models for its origin: (1) the modern-active-till model, and (2) the relict-till model.

The modern-active-till model was described in detail by Alley et al. (1986, 1987a, 1989) and is based on the hypothesis that the UpB till layer undergoes continuous viscous deformation throughout its thickness and erodes its substrata. However, subsequent studies of the till failed to validate some of the basic assumptions of this model. In particular, laboratory experiments indicate that the rheology of the UpB till is plastic rather than viscous (Kamb 1991) and borehole observations suggest that basal sliding (sensu lato) and not a viscous-like till deformation is the predominant mechanism for the fast ice-stream motion at the UpB camp (Engelhardt and Kamb in press). Alley et al. (1986, 1987a) used the relatively high porosity of the UpB till (c. 40\%, Blankenship et al. 1986; Engelhardt et al. 1990) as the main evidence for ongoing subglacial till deformation, but such high porosity is not inconsistent with till deposition from basal ice (Ronnert and Mickelson 1992).

We propose an alternative model for the origin of the UpB till, and detailed, quantitative discussion of this model will be given in a separate publication. In summary, we hypothesize that the till is a relict glacial deposit formed under a previous glacial regime. For instance, this till could have been generated in the past by sediment release from melting, debrisladen basal ice. The modern, debris-poor base of the ice stream may be sliding over a relict till layer without inducing any obvious changes in its properties.

A key question is which of these two models is more consistent with the lack of significant recent subglacial comminution and the recycling of glacimarine material into the UpB till that we have documented. Unfortunately, the limited knowledge about glacial comminution beneath ice overriding unconsolidated sediments makes it difficult to address this question. Despite recent advances on this topic (e.g., Hooke and Iverson 1995; Iverson et al. 1996), current understanding of comminution is based mainly on data and theories relevant to ice in contact with solid bedrock (Iverson 1995). There is clearly no consensus regarding the basic ability of subglacial deforming tills to comminute their debris. For instance, Elson (1988) believes that lack of comminution is one of the characteristic features of deformation tills. Conversely, other workers propose that deforming subglacial tills are reasonably efficient as agents of glacial comminution (Boulton et al. 1974; Clark 1991; Iverson et al. 1996). Dreimanis (1990, p. 41 and 42) points out that also in the case when till is deposited via basal ice (as in our relict-till model), both comminutive production of debris and recycling of preexisting sediments are possible.

Because of these uncertainties, it appears at present unattainable to constrain the exact origin of the UpB till on the basis of its textural and compositional properties. However, our data can be used to improve understanding of the physical conditions that prevent significant comminution and permit recycling of preexisting sediments into tills. In the following discussion, we interpret the relationship of the observed sediment characteristics of the UpB till to these basal physical conditions that have been independently constrained and are not model-dependent.

Notwithstanding the uncertainty regarding the exact role of subglacial deformation in the genesis of the UpB till (e.g., Alley et al. 1989 vs. Engelhardt and Kamb in press), it is clear that this till experiences some deformation in its uppermost zone subjacent to the ice base. However, there are no recognizable signs of comminution at the tops of the $\mathrm{UpB}$ cores and fragile diatom shells are significantly more abundant here, providing compelling evidence for a lack of significant comminution in this zone (Table 2). This observation is consistent with Elson's (1988) conjecture that till deformation does not cause significant glacial comminution. The Pleistocene tills, which provide the observational basis for Elson's hypothesis, were deposited predominantly in young sedimentary (lacustrine) basins filled with weak, fine-grained sediments. This is a geologic setting similar to that beneath Ice Stream B, which also overrides a sedimentary (glacimarine) basin.

We propose that the weakness of comminution in the UpB till is ultimately due to its setting over the easily erodible, clay-rich, poorly indurated Miocene sediments. Although the material beneath the UpB till was not recovered in our cores, the existing geophysical and geological evidence indicates that these subtill sediments may be only moderately stronger than the weak till itself. The low seismic velocity of the till substrata (1.9-2.25 $\mathrm{km} / \mathrm{s}$ ) is consistent with their interpretation as poorly indurated sediments (Alley et al. 1989, p. 136). The most likely analog for the subtill material at UpB are the Miocene pebbly muds underlying glacial tills in the Ross Sea. They have similarly low seismic velocity $(1.67-2.09 \mathrm{~km} / \mathrm{s}$; Barrett and Froggatt 1978, their table 3). Split cores containing these muds show predominantly ductile deformation, which is typical for unlithified sediments (Hayes, Frakes, et al. 1975, p. 315-318). The strength of such ductile, finegrained material should be significantly less than a few MPa (the strength of a lithified mudstone; Iverson et al. 1996). However, the coarse particles in the UpB till are made up of much stronger minerals and rocks (quartz, feldspar, crystalline rocks, $100 \mathrm{MPa}$; Jaeger and Cook 1969, p. 146; Savanick and Johnson 1974). Erosion is likely to be able to excavate these strong particles from a weaker matrix without significant comminution and with preservation of the original textural properties (e.g., Mazzullo and Ritter 1991).

In addition, modeling of subglacial groundwater flow indicates that the 
location of Ice Stream B over clay-rich, low-permeability sediments, facilitates buildup of very high subglacial pore-water pressures (Tulaczyk et al. 1996). This result agrees with geophysical and borehole data which indicate that at present almost all of the ice overburden (c. $9 \mathrm{MPa}$ ) is borne by the pore water and very little is partitioned onto the solid skeleton of the till, which remains poorly consolidated and weak (Blankenship et al. 1986, 1987; Engelhardt et al. 1990). The high porosity of the UpB till ( 40\%) is consistent with subglacial pore-water pressures that are only several kilopascals below the overburden pressure (Engelhardt, unpublished data). These conditions hinder subglacial comminution, because the average interparticle stresses are several orders of magnitude smaller than the intrinsic strength of mineral and rock particles.

The fine-grained character of the UpB till also diminishes interactions between coarse particles (e.g., buildup of grain bridges), which are the most conducive for subglacial comminution (Sharp and Gomez 1986; Hooke and Iverson 1995; Iverson et al. 1996). When pore spaces (c. 40\%) and fines are excluded, the volumetric content of sand-size or larger particles in the UpB till is only c. $20 \%$ and that of pebbles is only a few percent. In the present work, we examined under an optical microscope c. $200 \mathrm{~cm}^{2}$ of thin-sectioned UpB till and found no grain bridges; even contacts between two sand grains are rare. In addition, abundance of fines in tills inhibits local stress concentrations between larger grains in the event that they do make contact (Iverson 1995; Whalley 1978). This "cushioning" effect of fines has been recognized as an important factor in suppressing comminution and is well documented by ball-mill (Austin and Bagga 1979) and ring-shear experiments (Iverson et al. 1996; Iverson et al. in press).

In Appendix A we develop a simple physical model that illustrates how difficult it is to induce breakage in a grain surrounded by a weak matrix of plastic rheology. We consider only the case that maximizes loading on a single grain in contact with one other grain. The condition for grain failure from this model is $T \sim 3.6 k$, where $T$ is the tensile strength of the grain and $k$ is the yield strength of the till matrix. Only grains made up of very weak materials $(T<36 \mathrm{kPa}$ for $k<10 \mathrm{kPa}$, consistent with Kamb 1991) could be broken in the UpB till by the considered mechanism, and thus common minerals and rocks $(\sim 100 \mathrm{MPa})$ could not be broken.

\section{Geologic Control on Development of Weak Sub-Ice-Stream Tills?}

Our findings provide evidence inconsistent with derivation of the UpB till by subglacial erosion of lithified bedrock (Boulton 1987, p. 26; Alley et al. 1987b; Rooney et al. 1987). In contrast, they indicate that this deposit formed by recycling of preexisting poorly indurated sediments (Alley et al. 1989, p. 136). This distinction is important because glacial erosion of strong, brittle rocks is quantitatively and qualitatively different from glacial erosion of sediments. Erosion of bedrock proceeds at rates that are orders of magnitude slower than erosion of sediments, and the resulting debris is relatively coarse and bears evidence of glacial comminution (Cuffey and Alley 1996; Iverson 1995). Thus, the geologic setting of an ice mass puts significant constraints on the formation rate and the characteristics of a subglacial till.

We hypothesize that the presence of preexisting poorly indurated source sediments strongly facilitates development of a weak till layer like the one that lubricates the base of Ice Stream B. This hypothesis is consistent with the recent geophysical findings that the onset of Ice Stream B may coincide with the boundary between a subglacial sedimentary basin and solid bedrock (Bell et al. 1996). Additional support for our proposition comes from the fact that past ice streams seem to have been preferentially located over glaciated marine or lacustrine basins filled with low-permeability, weak sediments (e.g., Hudson Bay Ice Stream, ice lobes in basins of Great Lakes; Alley and MacAyeal 1994; Hicock and Dreimanis 1992). This possibility of significant geologic control on distribution and mechanics of ice streams is intriguing and important, and it can be tested by further geophysical and borehole studies of subglacial environments beneath modern ice streams and their surroundings.

\section{CONCLUSIONS}

We interpret that the clay-rich diamicton recovered in the five 1-3 m long cores from beneath Ice Stream B represents the widespread subglacial till whose presence in the UpB area was inferred previously from seismic data (Blankenship et al. 1986, 1987; Rooney et al. 1987). The wide range of microfossil ages and the relatively low microfossil abundance in this diamicton suggest that it experienced glacial mixing and transport and that it is not an in situ Tertiary glacimarine deposit. The textural and compositional characteristics of the UpB till, however, appear to be inherited from the (inferred) subtill Miocene glacimarine pebbly muds that belong to the Tertiary sedimentary sequence of the Ross Sea basin. This makes the till sedimentologically very similar to the Plio-Pleistocene diamictons that are found throughout most of the Ross Sea and which are usually interpreted as basal tills (Anderson et al. 1980; Kellogg et al. 1979). On the other hand, the UpB till differs from many other tills because of the lack of evidence for significant subglacial crushing and abrasion, which is considered to be particularly characteristic for subglacial deposits.

The analyzed textural and compositional properties of the UpB till cannot be used to conclusively verify whether this till is a modern viscously deforming till or a relict glacial deposit formed under a glacial regime quite different from the current ice-stream setting. However, because some till deformation does occur near the top of the till (Engelhardt and Kamb in press), our data support the proposition that subglacial deformation of weak, fine-grained tills does not result in significant glacial comminution (Elson 1988). In the case of the UpB till, the inefficient subglacial comminution may be ultimately a result of its setting over the (inferred) finegrained glacimarine source sediments. Glacial erosion of such weak material takes place without significant abrasion and crushing, and the resulting fine-grained till matrix facilitates high subglacial pore-water pressure and efficiently "cushions" the coarser particles from comminution.

Since the geologic setting of Ice Stream B has such a profound influence on the properties of the UpB till, we hypothesize that the development of similar extensive layers of weak till takes place preferentially where ice overrides preexisting, poorly indurated, fine-grained sediments. This hypothesis needs to be further tested because it has the potential to enhance the existing limited understanding of the controls that determine the location, geometry, and basal mechanics of ice streams.

\section{ACKNOWLEDGMENTS}

This project was funded by grant OPP-9219279 from the National Science Foundation. Partial support was provided to R. Scherer by NSF grant OPP-9496169 and the Swedish Natural Science Research Council and to S. Tulaczyk by the Henry and Grazyna Bauer Fellowship. Rowena Lohman provided essential help with laboratory analyses and James Spotila and Miriam Jackson with thorough reviews of an early version of this manuscript. We thank Richard Alley, Lincoln Pratson, and an anonymous reviewer for helpful criticisms, some of which are not answered here. Contribution 8506, Division of Geological and Planetary Sciences, California Institute of Technology.

\section{REFERENCES}

AlLEY, R.B., 1991, Deforming-bed origin for southern Laurentide till sheets: Journal of Glaciology, v. 37 , p. $67-76$.

Alley, R.B., AND MacAyeal, D.R., 1994, Ice-rafted debris associated with binge/purge oscillations of the Laurentide Ice Sheet: Paleoceanography, v. 9, p. 503-511.

Alley, R.B., Blankenship, D.D., Bentley, C.R., And Rooney, S.T., 1986, Deformation of till beneath Ice Stream B, West Antarctica: Nature, v. 322, p. 57-59.

Alley, R.B., Blankenship, D.D., Bentley, C.R., and Rooney, S.T., 1987a, Till beneath Ice Stream B, 3. Till deformation: evidence and implications: Journal of Geophysical Research, v. 92, p. 8921-8929.

Alley, R.B., BlankenshiP, D.D., Rooney, S.T., And Bentley, C.R., 1987b, Continuous till deformation beneath ice sheets, in Waddington, E.D., and Walder, J.S., eds., The Physical Basis of Ice Sheet 
Modelling: Wallingford, U.K., International Association of Hydrological Sciences, Publication 170, p. 81-90.

Alley, R.B., Blankenshir, D.D., Rooney, S.T., and Bentley, C.R., 1989, Water-pressure coupling of sliding and bed deformation: III. Application to Ice Stream B, Antarctica: Journal of Glaciology, v. 35 , p. $130-139$

Anderson, J.B., Brake, C.F., and Myers, N.C., 1984, Sedimentation on the Ross Sea continental shelf, Antarctica: Marine Geology, v. 57, p. 295-333.

Anderson, J.B., KurtZ, D.D., Domack, E.W., AND Balshaw, K.K., 1980, Glacial and glacial marine sediments of the Antarctic continental shelf: Journal of Geology, v. 88, p. 399-414.

AnDERSON, R.C., 1955, Pebble lithology of the Marseilles till sheet in northeastern Illinois: Journal of Geology, v. 63, p. 228-243.

Austin, L.G., AND BAGGA, P., 1981, An analysis of fine dry grinding in ball mills: Powder Technology, v. 28, p. $83-90$

BARRETT, P.J., 1975a, Textural characteristics of Cenozoic preglacial and glacial sediments at site 270, Ross Sea, Antarctica, in Hayes, D.E., and Frakes, L.A., eds., Initial Reports of the Deep Sea Drilling Project, v. 28, U.S. Government Printing Office, Washington D.C., p. 757-767.

BARRETT, P.J., 1975b, Characteristics of pebbles from Cenozoic marine glacial sediments in the Ross Sea (DSDP sites 270-274) and the South Indian Ocean (site 268), in Hayes, D.E., and Frakes, L.A., eds., Initial Reports of the Deep Sea Drilling Project, v. 28, U.S. Government Printing Office, Washington D.C., p. 769-773

BarRett, P.J., and FroggatT, P.C., 1978, Densities, porosities, and seismic velocities of some rocks from Victoria Land, Antarctica: New Zealand Journal of Geology and Geophysics, v. 21, p. 175 187.

Bell, R.E., Blankenship, D.D., Finn, C.A., Morse, D.L., and Scambos, T.A., 1996, Evidence for geologic control of ice sheet behavior: The onset of ice streaming in West Antarctica (abstract): EOS, American Geophysical Union Transactions, v. 77, Fall Meeting Supplement, p. F140.

BentLEY, C.R., 1982, Crustal structure of Antarctica from geophysical evidence-a review, in Oliver, R.L., James, P.R., and Jago, J.B., eds., Antarctic Earth Science: Cambridge, U.K., Cambridge University Press, p. 491-497.

BeNTLEy, C.R., 1987, Antarctic ice streams: a review: Journal of Geophysical Research, v. 92, p. 8843-8858.

BerneR, R.A., AND HoldRen, G.R., 1977, Mechanism of feldspar weathering: Some observational evidence: Geology, v. 5, p. 369-372.

BERNER, R.A., AND HoldREN, G.R., 1979, Mechanism of feldspar weathering-II. Observations of feldspars from soils: Geochimica et Cosmochimica Acta, v. 43, p. 1173-1186.

Bindschadler, R.A., Koci, B., And Iken, A., 1988, Drilling on Crary Ice Rise, Antarctica: Antarctic Journal of the United States, v. 23, p. 60-61.

Blankenship, D.D., Bentley, C.R., Rooney, S.T., and Alley, R.B., 1986, Seismic measurements reveal a saturated porous layer beneath an active Antarctic ice stream: Nature, v. 322, p. 54-57.

Blankenship, D.D., Bentley, C.R., Rooney, S.T., and Alley, R.B., 1987, Till beneath Ice Stream B, 1. Properties derived from seismic travel times: Journal of Geophysical Research, v. 92, p. 89038911.

Boulton, G.S., 1987, Progress in glacial geology during the last fifty years: Journal of Glaciology, v. 33, special issue, p. 25-32.

Boulton, G.S., 1996, Theory of glacial erosion, transport and deposition as a consequence of subglacial sediment deformation: Journal of Glaciology, v. 42, p. 43-62.

Boulton, G.S., Dent, D.L., AND MorRIs, E.M., 1974, Subglacial shearing and crushing and the role of water pressures in tills from south-east Iceland: Geografiska Annaler, v. 56, p. 121-134.

BridLe, I.M., and Robinson, P.H., 1989, Diagenesis, in Barrett, P.J., ed., Antarctic Cenozoic History from the CIROS-1 Drillhole, McMurdo Sound: New Zealand Department of Scientific and Industrial Research, Bulletin, v. 245, p. 201-207.

Clark, P.U., 1991, Striated clast pavements: Products of deforming bed? Geology, v. 19, p. 530533.

CLARK, P.U., 1992, Surface form of the southern Laurentide Ice Sheet and its implications to icesheet dynamics: Geological Society of America, Bulletin, v. 104, p. 595-605.

Clark, P.U., and Walder, J.S., 1994, Subglacial drainage, eskers, and deforming beds beneath the Laurentide and Eurasian ice sheets: Geological Society of America, Bulletin, v. 106, p. 304-314

CufFey, K., AND AlLEY, R.B., 1996, Is erosion by deforming subglacial sediments significant? (Toward till continuity): Annals of Glaciology, v. 22, p. 1-19.

DARMODY, R.G., 1985, Weathering assessment of quartz grains: a semiquantitative approach: Soil Science Society of America, Journal, v. 49, p. 1322-1324.

Domack, E.W., Anderson, J.B., AND KuRTZ, D.D., 1980, Clast shapes as indicator of transport and depositional mechanisms in glacial marine sediments: Journal of Sedimentary Petrology, v. 50, p. 813-820.

Douglas L.A., AND PlatT, D.W., 1977, Surface morphology of quartz and age of soils: Soil Science Society of America, Journal, v. 41, p. 641-645.

DrAKE, L.D., 1972, Mechanisms of clast attrition in basal till: Geological Society of America, Bulletin, v. 83 , p. $2159-2166$.

DreimanIS, A., 1988, Tills: their genetic terminology and classification, in Goldthwait, R.P., and Matsch, C.L., eds., Genetic Classification of Glacigenic Deposits: Rotterdam, A.A. Balkema, p. 17-83.

DreImanis, A., 1990, Formation, deposition, and identification of subglacial and supraglacial tills, in Kujansuu, R., and Saarnisto, M., eds., Glacial Indicator Tracing: Rotterdam, A.A. Balkema, p. $35-60$.

Dreimanis, A., AND VaGners, U.J., 1969, Lithologic relation of till to bedrock, in Wright, H.E., ed., Quaternary Geology and Climate: Washington D.C., National Academy of Sciences, p. 93-98.

Dreimanis, A., AND VAGNERS, U.J., 1971, Bimodal distribution of rock and mineral fragments in basa tills, in Goldthwait, R.P., ed., Till; A Symposium: Columbus, Ohio, Ohio State University Press, p. 237-250.

Echelmeyer, K.A., Harrison, W.D., LaRsen, C., and Mitchell, J.E., 1994, The role of the margins in the dynamics of an active ice stream: Journal of Glaciology, v. 40, p. 527-538.

ELSON, J.A., 1988, Comment on glacitectonite, deformation till, and comminution till, in Goldthwait,
R.P., and Matsch, C.L., eds., Genetic Classification of Glacigenic Deposits: Rotterdam, A.A. Balkema, p. 85-88.

ENGELHARDT, H.F., AND KAMB, B., 1993, Vertical temperature profile of ice stream B: Antarctic Journal of the United States, v. 28, p. 63-66.

EngelHaRdT, H.F., AND KAMB, B., 1997, Sliding velocity of Ice Stream B: Journal of Glaciology, v. 43, p. 207-230.

ENGelHARDT, H.F., AND KAMB, B., In press, Basal hydraulic system of a West Antarctic ice stream: constraints from borehole observations: Journal of Glaciology.

Engelhardt, H.F., Humphrey, N., Kamb, B., and Fahnestock, M., 1990, Physical conditions at the base of a fast moving Antarctic ice stream: Science, v. 248, p. 57-59.

Galehouse, J.S., 1971a, Point counting, in Carver, R.E., ed., Procedures in Sedimentary Petrology: New York, Wiley-Interscience, p. 385-407.

Galehouse, J.S., 1971b, Sedimentation analysis, in Carver, R.E., ed., Procedures in Sedimentary Petrology: New York, Wiley-Interscience, p. 69-94.

George, A., 1989, Sand provenance, in Barrett, P.J., ed., Antarctic Cenozoic History From the CIROS-1 Drillhole, McMurdo Sound: New Zealand Department of Scientific and Industrial Research, Bulletin, v. 245, p. 159-163.

GLLbERG, G., 1977, Redeposition: a process in till formation: Geologiska Föreningens i Stockholm Förhandlingar, v. 99, p. 246-253.

Gow, A., UEDA, H., AND GARFIELD, D., 1968, Antarctic ice sheet: preliminary results of first core hole to bedrock: Science, v. 161, p. 1011-1013.

GrIFFIN, G.M., 1971, Interpretation of X-ray diffraction data, in Carver, R.E., Procedures in Sedimentary Petrology: New York, Wiley-Interscience, p. 541-569.

HALDORSEN, S., 1977, The petrography of tills—a study from Ringsaker, south-eastern Norway: Norges Geologiske Undersøkelse, v. 336, p. 1-36.

HaldoRsen, S., 1981, The enrichment of quartz in tills, in Evenson, E.B., Schluchter, C., and Rabassa, J., Tills and Related Deposits: Rotterdam, A.A. Balkema, p. 141-150.

HALDORSEN, S., 1983, Mineralogy and geochemistry of basal till and their relationship to till-forming processes: Norsk Geologisk Tidsskrift, v. 63, p. 15-25.

HALl, K.J., 1989, Clast shape, in Barrett, P.J., ed., Antarctic Cenozoic History from the CIROS-1 Drillhole, McMurdo Sound: New Zealand Department of Scientific and Industrial Research, Bulletin, v. 245 , p. $63-67$

Harland, W.B., Herool, K.N., AND KRinsley, D.H., 1966, The definition and identification of tills and tillites: Earth-Science Reviews, v. 2, p. 225-256.

Harwood, D.M., Scherer, R.P., and WebB, P.-N., 1989, Multiple Miocene productivity events in West Antarctica as recorded in Upper Miocene sediments beneath the Ross Ice Shelf (Site J-9): Marine Micropaleontology, v. 15, p. 91-115.

HAYES, D.E., AND FrakEs, L.A., 1975, General synthesis, in Hayes, D.E., and Frakes, L.A., eds., Initial Reports of the Deep Sea Drilling Project, v. 28, U.S. Government Printing Office, Washington D.C., p. 919-942

HAYES, D.E. FRAKES, L.A., ET AL, 1975, Sites 270, 271, 272, in Hayes, DE, and Frakes, L.A. eds Initial Reports of the Deep Sea Drilling Project, v. 28, U.S. Government Printing Office, Washington D.C., p. 211-334.

Herron, S., and Langway, C.C., 1979, The debris-laden ice at the bottom of the Greenland ice sheet: Journal of Glaciology, v. 23, p. 193-207.

Hicock, S.R., AND Dreimanis, A., 1992, Deformation till in the Great Lakes region: implication for rapid flow along the south-central margin of the Laurentide Ice Sheet: Canadian Journal of Earth Sciences, v. 29, p. $1565-1579$.

Hiramatsu, Y., AND OKa, Y., 1966, Determination of the tensile strength of rock by a compression test of an irregular test piece: International Journal of Rock Mechanics and Mining Sciences, v. 3, p. 89-99.

HobBs, D.W., 1974, The tensile strength of rocks: International Journal of Rock Mechanics and Mining Sciences, v. 1, p. 385-396.

HOLDREN, G.R., AND BERNER, R.A., 1979, Mechanism of feldspar weathering-I. Experimental studies: Geochimica et Cosmochimica Acta, v. 43, p. 1161-1171.

Holmes, C.D., 1952, Drift dispersion in west-central New York: Geological Society of America, Bulletin, v. 63, p. 993-1010.

HOOKE, R.L., AND IvERSON, N.R., 1995, Grain-size distribution in deforming subglacial tills: role of grain fracture: Geology, v. 23, p. 57-60.

HugHes, T., 1996, Can ice sheets trigger abrupt climatic change?: Arctic and Alpine Research, v. 28, p. $448-465$.

IVERSON, N.R., 1995, Processes of erosion, in Menzies, J., ed., Modern Glacial Environments; Processes, Dynamics, and Sediments: Oxford, U.K., Butterworth Heinemann, p. 241-260.

IVERSON, N.R., BAKER, R.W., AND HOOYER, T.S., in press, A ring shear device for the study of till deformation: Tests on tills with contrasting clay content: Quaternary Science Reviews.

Iverson, N.R., HoOYer, T., AND HoOKE, R.L., 1996, A laboratory study of sediment deformation, stress heterogeneity and grain-size evolution: Annals of Glaciology, v. 22, p. 167-175.

JAEGER, J.C., AND COOK, N.G.W., 1969, Fundamentals of Rock Mechanics: London, Methuen, $513 \mathrm{p}$.

JACKSON, M., AND KAMB, B., in press, The marginal shear stress of Ice Stream B: Journal of Glaciology

JANKOWSKI, E.J., AND Drewry, D.J., 1981, The structure of West Antarctica from geophysical studies: Nature, v. 291, p. 17-21.

Johnson, A.M., 1970, Physical Processes in Geology: San Francisco, Freeman, Cooper, 577 p.

КАмв, B., 1991, Rheological nonlinearity and flow instability in the deforming-bed mechanism of ice stream motion: Journal of Geophysical Research, v. 96, p. 16,585-16,595.

Kamb, B., and EngelhardT, H., 1991, Antarctic ice stream B: conditions controlling its motion and interactions with the climate system, in Kotlyakov, V.M. Ushakov, A., and Glazovsky, A., Glaciers-Ocean-Atmosphere Interactions: Wallingford, U.K., International Association of Hydrological Sciences, Publication 208, p. 145-154.

Kanaori, Y., TanaKa, K., and Miyakoshi, K., 1985, Further studies on the use of quartz grains from fault gouges to establish the age of faulting: Engineering Geology, v. 21, p. 175-194. KarRow, P.F., 1976, The texture, mineralogy, and petrography of North American tills, in 
Legget, R.F., ed., Glacial Till, An Inter-Disciplinary Study: Royal Society of Canada, Special Publication 12, p. 83-98.

Kellogg, T.B., Truesdale, R.S., and Osterman, L.E., 1979, Late Quaternary extent of the West Antarctic ice sheet: new evidence from Ross Sea cores: Geology, v. 7, p. 249-253.

Kemmis, T.J., 1981, Importance of regelation process to certain properties of basal tills deposited by the Laurentide ice sheet in Iowa and Illinois, U.S.A.: Annals of Glaciology, v. 2, p. 147-152.

Krinsley, D.H., And Doornkamp, J.C., 1973, Atlas of Quartz Sand Surface Textures: Cambridge, U.K., Cambridge University Press, 96 p.

KRumbein, W.C., 1941, Measurement and geological significance of shape and roundness of sedimentary particles: Journal of Sedimentary Petrology, v. 11, p. 64-72.

Kump, L.R., AND Alley, R.B., 1994, Global chemical weathering on glacial time scales, in Hay, W.W., ed., Material Fluxes on the Surface of the Earth: Washington D.C., National Academy Press, p. 46-60.

Laws, R.A., 1983, Preparing strewn slides for quantitative microfossil analysis: A test using calibrated microspheres: Micropaleontology, v. 29, p. 60-65.

MacAyeal, D.R., 1992, Irregular oscillations of the West Antarctic ice sheet: Nature, v. 359, p. 29-32.

MAHANEY, W.C., 1995, Glacial crushing, weathering, and diagenetic history of quartz grains inferred from Scanning Electron Microscopy, in Menzies, J., ed., Modern Glacial Environments; Processes, Dynamics, and Sediments: Oxford, U.K., Butterworth Heinemann, p. 487506.

Margolis, S.V., And KennetT, J.P., 1971, Cenozoic glacial history of Antarctica recorded in subantarctic deep-sea cores: American Journal of Science, v. 271, p. 1-36.

Mazzullo, J., AND Anderson, J.B., 1987, Grain shape and surface texture analysis of till and glaci-marine sand grains from the Weddell and Ross Seas, Antarctica, in Marshall, J.R., ed., Clastic Particles: New York, Van Nostrand Reinhold, p. 314-327.

Mazzullo, J., ANd RitTer, C., 1991, Influence of sediment source on the shapes and surface textures of glacial quartz sand grains: Geology, v. 19, p. 384-388.

Mickelson, D.M., Clayton, L., Fullerton, D.S., and Borns, H.W., 1983, The Late Wisconsin glacial record of the Laurentide Ice Sheet in the United States, in Wright, H.E., and Porter, S.C., eds., Late-Quaternary Environments in the United States, vol. 1: Minneapolis, Minnesota, University of Minnesota Press, p. 3-37.

RonNeRT, L., AND Mickelson, D.M., 1992, High porosity of basal till at Burroughs Glacier, Southeastern Alaska: Geology, v. 20, p. 849-852.

Rooney, S.T., Blankenship, D.D., Alley, R.B., and Bentley, C.R., 1987, Till beneath Ice Stream B, 2. Structure and continuity: Journal of Geophysical Research, v. 92, p. 89138920.

Rooney, S.T., Blankenship, D.D., Alley, R.B., and Bentley, C.R., 1991, Seismic reflection profiling of a sediment-filled graben beneath Ice Stream B, West Antarctica, in Thomson, M.R., Crame, J.A., and Thomson, J.W., eds., Geological Evolution of Antarctica: Cambridge, U.K., British Antarctic Survey, p. 261-265.

RosENQvist, I.T., 1962, What is the origin of the hydrous micas in Fennoscandia? Geological Institutions of the University of Uppsala, Bulletin, v. 40, p. 265-268.

Rosenqvist, I.T., 1975, Origin and mineralogy of glacial and interglacial clays of southern Norway: Clays and Clay Minerals, v. 23, p. 153-159.

Savage, M.L., And Ciesielski, P.F., 1983, A revised history of glacial sedimentation in the Ross Sea region, in Oliver, R.L., James, P.R., and Jago, J.B., eds., Antarctic Earth Science: Cambridge, U.K., Cambridge University Press, p. 555-559.

Savanick, G.A., AND Johnson, D.I., 1974, Measurements of the strength of grain boundaries in rock: International Journal of Rock Mechanics, Mining Sciences and Geomechanical Abstracts, v. 11 , p. $173-180$.

SCHERER, R.P., 1989, Microfossil assemblages in "deforming till" from Upstream B, West Antarctica: implications for ice-stream flow models: Antarctic Journal of the United States, v. 24 , p. $54-55$.

SCHERER, R.P., 1991, Quaternary and Tertiary microfossils from beneath Ice Stream B: evidence for a dynamic West Antarctic Ice Sheet history: Palaeogeography, Palaeoclimatology, Palaeoceanography, v. 90 , p. 395-412.

SCHERER, R.P., 1994, A speculative stratigraphic model for the central Ross embayment: Antarctic Journal of the United States., v. 29, p. 9-11.

Sharp, M., and Gomez, B., 1986, Process of debris comminution in the glacial environment and implications for quartz sand-grain micromorphology: Sedimentary Geology, v. 46, p. 33-47.

SLAdEn, J.A., AND Wrigley, W., 1983, Geotechnical properties of lodgement till—a review, in Eyles, N., ed., Glacial Geology, An Introduction for Engineers and Earth Scientists: Oxford, U.K., Pergamon Press, p. 184-212.

SмIтH, A.M., 1997, Basal conditions on Rutford Ice Stream, West Antarctica, from seismic observations: Journal of Geophysical Research, v. 102, p. 543-552

Sugden, D.E., Knight, P.G., Livesey, N., Lorrain, R.D., Souchez, R.A., Tison, J.-L., And Jouzel, J., 1987, Evidence for two zones of debris entrainment beneath the Greenland ice sheet: Nature, v. 328, p. 238-241.

Tulaczy, S., Engelhardt, H.F., and Kamb, B., 1996, Role of groundwater in maintaining low basal effective pressures beneath Ice Stream B, West Antarctica (abstract): EOS, American Geophysical Union Transactions, v. 77, Fall Meeting Supplement, p. F212.

TURNER, J.W., 1992, Dispersal and provenance of fine-grained sediments and the influence of marine transgression on the Ross Sea continental shelf, Antarctica [unpublished Ph.D. thesis]: Columbus, Ohio, Ohio State University, 284 p.

WebB, P.N., 1979, Initial report on geological materials collected at RISP Site J9: RISP Technical Report 79-1, Ross Ice Shelf Project Management Office, Lincoln, Nebraska, 126 p.

Whalley, W.B., 1978, An SEM examination of quartz grains from subglacial and associated environments and some methods for their characterization: Scanning Electron Microscopy, v. $1978 /$ I, p. $353-360$.

Whillans, I.M., AND VAN DER Veen, C.J., 1993, New and improved determinations of velocity of Ice Stream B and C, West Antarctica: Journal of Glaciology, v. 39, p. 483-490.

Zhang, J., Wong, T-F., and Davis, D.M., 1990, Micromechanics of pressure-induced grain crushing in porous rocks: Journal of Geophysical Research, v. 95, p. 341-352.

Received 30 July 1996; accepted 11 September 1997.

\section{APPENDIX A-GRAIN CRUSHING}

Failure of grains can frequently be explained in terms of a buildup of elastic tensile stresses in the interior of a grain loaded on its boundaries (Hiramatsu and Oka 1966). For a grain in a perfectly plastic matrix, the maximum force that can be applied to any point on the grain surface is equal to the force that will result in plastic yielding around the hemisphere of the grain that lies opposite the point of loading (Fig. 8). When such yielding develops, the grain starts to move through the matrix. The maximum point load, $P$, is equal to the resistive force $F$ offered by the matrix, which can be estimated for a spherical particle on the basis of plasticity theory (Johnson 1970, p. 481):

$$
P=-F=(2+\pi) \pi k R^{2}
$$

where $k=$ plastic yield strength of the matrix and $R=$ radius of the grain.

We have not been able to find or derive an explicit solution for the distribution of elastic stresses in a grain under such an asymmetric load. We make a heuristic assumption that the loading is analogous to the Brazilian test. In that test, two point loads of equal magnitude and opposite direction are applied to a grain. Since an increase in an area over which a load is distributed causes a decrease in the magnitude of tensile stresses inside the grain (Hiramatsu and Oka 1966, their figure 5), this assumption is consistent with our intention to consider a buildup of maximum stresses for a given magnitude of the load $P$. Tensile stresses within a sphere loaded in the Brazilian test can be calculated analytically (Hiramatsu and Oka 1966, p. 97). At the center of the grain the tensile stress is

$$
\sigma_{t} \approx \frac{0.7 P}{\pi R^{2}}
$$

Substituting for applied load $P(\mathrm{Eq} 1)$,

$$
\sigma_{t} \approx 3.6 k
$$

A failure of the loaded grain will occur only if the tensile stress reaches the tensile strength of the grain, i.e., $T \approx \sigma_{1} \approx 3.6 \mathrm{k}$.

In our treatment we omitted the possibility of grain failure due to high tensile stresses building up on the grain surface around the Hertzian contact between grains. Experimental and theoretical results of Zhang et al. (1990) suggest that the Hertziancontact mechanism produces significant breakage of natural materials at loads similar to those of the Brazilian test (Hobbs 1974). Thus, our simple model provides a representative treatment of grain breakage in a plastic matrix.

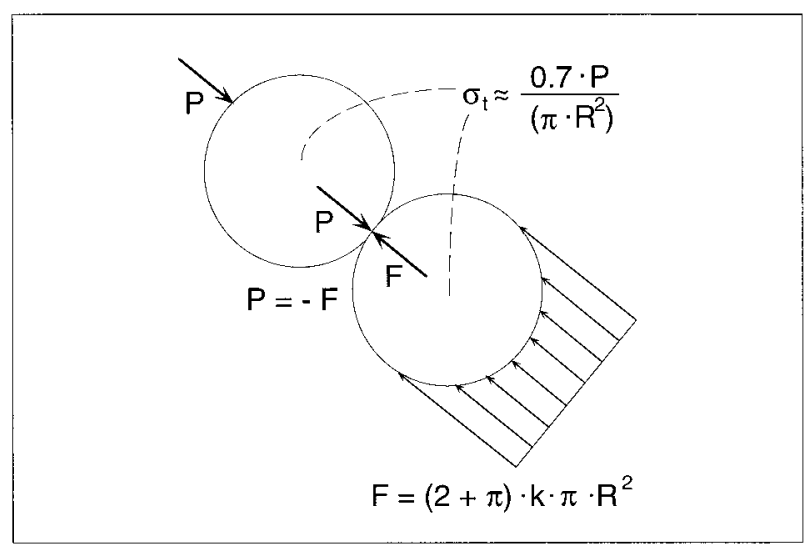

FIG. 8.-Contact of two spherical grains in a perfectly plastic matrix. Grain to the upper left is pressed against the lower grain because of some arbitrary mechanism. Maximum load $\mathrm{P}$ on the second grain occurs when the perfectly plastic matrix starts to yield and the grain moves in the direction of loading. Mathematical symbols are explained in the text. 